\title{
Long-term clinical, immunologic and virologic impact of glucocorticoids on the chronic phase of HIV infection Jean-Marie Andrieu* and Wei Lu
}

Address: Institut de Recherche sur les Vaccins et l'Immunothérapie des cancers et du SIDA (IRVICS), Laboratoire d'Oncologie et Virologie Moléculaire, Centre Biomédical des Saints-Pères, Université René Descartes, 75270 Paris, Cedex 06, France

Email: Jean-Marie Andrieu* - jean-marie.andrieu@biomedicale.univ-paris5.fr; Wei Lu - louis.wei-lu@biomedicale.univ-paris5.fr

* Corresponding author

Published: 05 May 2004

BMC Medicine 2004, 2:17
Received: 03 December 2003

Accepted: 05 May 2004

This article is available from: http://www.biomedcentral.com/174I-70I5/2/17

(C) 2004 Andrieu and Lu; licensee BioMed Central Ltd. This is an Open Access article: verbatim copying and redistribution of this article are permitted in all media for any purpose, provided this notice is preserved along with the article's original URL.

\begin{abstract}
Background: To test the hypothesis of down-regulating the increased immune system activation/ destruction process associated with chronic HIV infection, we focused our interest on prednisolone (PDN), because we had showed that, in vitro, PDN had a strong anti-apoptotic activity on activated $\mathrm{T}$ cells of HIV-infected patients and no effect on viral replication. We thus designed in 1992 a pilot study to evaluate the clinical, immunologic and virologic effects of PDN. The drug was given to a group of 44 patients with CD4 T cells over 200/ $\mu$ l. After one year, no patient had developed clinical AIDS and the mean CD4 T cell count of the group had increased from $44 \mathrm{I} \pm 2 \mathrm{I}$ cells $/ \mu$ lo $553 \pm 43$ cells $/ \mu$ l. Moreover, markers of immune activation had dropped back to normal levels while the mean viral load of the group had remained unchanged. Here we explore the longterm clinical, immunologic, and virologic impact of prednisolone on the chronic phase of HIV infection.
\end{abstract}

Methods: Retrospective study over 10 years starting between July 1992 and February 1993. A total of 44 patients with CD4 cells/ $\mu$ ranging from 207 to 775 were treated with prednisolone, 0.5 $\mathrm{mg} / \mathrm{kg} / \mathrm{d}$, over 6 months and $0.3 \mathrm{mg} / \mathrm{kg} / \mathrm{d}$ thereafter.

Results: No clinical AIDS developed under prednisolone; side effects of the drug were mild. CD4 cells which increased from $42 \mathrm{I}$ cells/ $\mu$ at entry to 625 cells $/ \mu$ at day 15 , slowly decreased to reach 426 cells/ $\mu \mathrm{l}$ after two years; $T$ cell apoptosis and activation markers dropped within 15 days to normal levels and reincreased slowly thereafter. Serum viral loads remained stable. The percentage of patients maintaining CD4 cells over entry was $43.2 \%$ at two years, II.4\% at five years and $4.6 \%$ at 10 years. Initial viral load was highly predictive of the rate of CD4 decrease under prednisolone.

Conclusions: Prednisolone postponed CD4 cell decrease in a viral load dependent manner for a median of two years and for up to 10 years in a fraction of the patients with a low viral load. These findings might stimulate clinical trials as well as biological research on the role of antiapoptotic drugs in HIV infection.

\section{Background}

The human immunodeficiency virus type 1 (HIV) is a retrovirus which preferentially infects an important class of immune cells governing the immune system, the lymphocytes of the $\mathrm{CD}_{4}+$ phenotype. HIV infection leads to a complex immunologic disorder combining a progressive 
decrease in CD4 T cells and a chronic activation of T and $B$ cells, associated with increased serum concentrations of $\beta 2$ microglobulin and other immune activation markers. After three to 20 years of CD4 T cell depletion and immune activation, which are generally clinically asymptomatic, the CD4 T cell pool eventually collapses and the various clinical manifestations of AIDS develop.

These observations (most of which were available in the middle of the 1980s) led us to be interested in immunosuppressive compounds as potential treatments of the chronic phase of HIV infection and tools to better understand its pathogenesis [1]. In September 1985 we thus started giving Cyclosporin A (CSA) for a year to a group of 27 patients with 300-600 CD4 cells/ $\mu \mathrm{l}$ [2]. Long-term follow-up of these patients showed that their mean CD4 cell count remained stable under CSA while it decreased after CSA withdrawal [3]. In 1992, we were still thinking that it was reasonable to test the hypothesis of pharmacologically down-regulating the increased activity of immune cells with the objective to slow down the HIV-induced immune system activation/destruction process. We focused our interest on prednisolone (PDN), an inexpensive drug belonging to the family of glucocorticoids (GCs), because we had showed that, in vitro, PDN had a strong anti-apoptotic activity on activated T cells of HIVinfected patients and no effect on viral replication [4]. We thus designed a pilot study to evaluate the clinical, immunologic and virologic effects of PDN. The drug was given to a group of $44 \mathrm{HIV}$-infected patients with CD4 T cells over 200/ $\mu$ l. After one year, no patient had developed clinical AIDS and the mean CD4 T cell count of the group had increased from $441 \pm 21$ cells $/ \mu$ l to $553 \pm 43$ cells $/ \mu$ l. Moreover, markers of immune activation had dropped back to normal levels while the mean viral load of the group had remained unchanged [5]. At completion of this one-year study, patients were offered to remain under PDN for a second year. From the third year, with the concurrence of the patients, we decided to maintain PDN as long as the patients' CD4 T cells remained above entry levels. Here, we present the 10-year results of this retrospective study.

\section{Methods}

\section{Patients}

Patient characteristics have already been described in detail elsewhere [5]. Briefly, 44 patients (36 men, eight women, mean age 36 years, 11 under zidovudine, 500 $\mathrm{mg}$ (day), a CD4 cell count ranging from 207 to 775 cells/ $\mu \mathrm{l}$ (mean \pm SE: $421 \pm 21$, median 438), no clinical AIDS, and no GC contra-indications entered in the pilot study between 1 July 1992 and 19 February 1993. All of them signed an informed consent before starting PDN. Among the 44 patients entered in the study, 25 had already been followed in our institution over the two preceding years with CD4 cell counts performed at least every six months and their serum frozen every year.

Oral PDN (Solupred, Laboratoire Houdé, Puteaux, France) was given at a daily dose of $0.5 \mathrm{mg} / \mathrm{kg}$ during the first six months and at $0.3 \mathrm{mg} / \mathrm{kg}$ thereafter. Once they had completed one year of PDN, patients were offered to stay under PDN, $0.3 \mathrm{mg} / \mathrm{kg} / \mathrm{day}$, for a second year. From the third to the tenth year, patients whose CD4 T cells remained over entry level were allowed to remain under PDN while the others were discouraged to pursue PDN. Patients who stopped PDN were recommended to decrease its dose over one to three months; they were also asked to start antiretroviral therapy (one or two reverse transcriptase inhibition (RTIs) until April 1996, or an association of two RTIs and one protease inhibitor (PI) after this date). Daily potassium and, from the second year on, calcium and vitamin D tablets as well as a low sodium diet were recommended to all patients as long as PDN was taken. Moreover, $P$. carinii prophylaxis by sulfamethoxazole and trimethoprim was administered to all patients during the first year.

Evaluation of the 44 patients entered in the pilot study was carried out in the three days preceding PDN onset (day 0), at two weeks, 11 weeks, four months and every other month during the first year. During the second year, evaluations were also performed every two months and from the third year, every three months. Clinical evaluation included measurements of weight and blood pressure as well as research of signs of hypercorticism. Biological evaluation comprised blood count with CD4 ${ }^{+}$ and $\mathrm{CD}^{+} \mathrm{T}$ lymphocyte phenotypes, glycemia and plasma $\mathrm{K}^{+}$concentration. A quantity of $4 \mathrm{ml}$ of serum was also frozen at each of the above-mentioned time points for $\beta 2$ microglobulin and viral load measurements. During the first year, percentages of $\mathrm{CD}_{2} 5^{+}$and $\mathrm{DR}^{+}$phenotypes in $\mathrm{CD}^{+} \mathrm{T}$ lymphocytes were measured in fresh samples while the percentage of apoptotic cells in peripheral blood mononuclear cells (PBMC) was assessed in frozen samples after overnight culture in the presence of antiCD3 monoclonal antibodies $(0.5 \mu \mathrm{g} / \mathrm{ml}$, Becton Dickinson) by a flow cytometry-based labelling technique [6].

\section{Control group}

With the aim of comparing the evolution of our PDNtreated group with that of a group representative of the natural history of HIV infection, 74 HIV-infected individuals were identified from our computerized files through the four following criteria: 1) first visit to our institution between January 1987 and March 1993; 2) 200 to 800 CD4 cells $/ \mu \mathrm{l}$, no clinical AIDS and no antiviral therapy at first visit; 3$)$ a CD4 cell count at least every six $( \pm 2)$ months over the two subsequent years (or to death if it occurred within this delay); and 4) a sample of serum 
frozen at first visit and at one and two years for viral load measurements. Over the first two years of observation, 37 of these 74 patients did not receive any anti-viral therapy, while the other 37 started zidovudine one to 23 months after their first visit to our institution (median six months). From the third year of observation on, all patients who conserved their CD4 T cells over entry levels were regularly followed at least until their CD4 T cells decreased to under such levels.

\section{Viral load measurements}

Serum viral loads were measured with a quantitative RTPCR assay, which was developed and validated in our laboratory [7]. In order to show the impact of initial viral load on the clinical outcome as well as on the evolution of biological parameters, we identified the median viral load value of the 44 patients at PDN onset. Out of the 44 patients entered in the study, 22 had a viral load over 30,000 copies $/ \mathrm{ml}$ (that is, $4.25 \log _{10}$ copies $/ \mathrm{ml}$ ) while the 22 others had a viral load under $4.25 \log _{10}$ copies $/ \mathrm{ml}$. PDN-treated patients with $>4.25 \log _{10}$ copies $/ \mathrm{ml}$ were included in the high viral load (HVL) subgroup and those with $<4.25 \log _{10}$ copies/ml in the low viral load (LVL) subgroup. Patients of the control group were also divided in HVL and LVL subgroups according to the same cut-off value $\left(<\right.$ or $>4.25 \log _{10}$ copies $/ \mathrm{ml}$ ).

\section{Statistics}

All mean values were given with their standard error (SE). Hematological, immunologic and virologic measures were compared in the same patients at entry and at different time points by the Wilcoxon matched paired single rank test (Wt). The Mann-Whitney test (MWt) was used to compare viral loads and CD4 cell counts of different groups at the same time points. Kaplan Meier analysis was used to evaluate the percentage of patients of different groups who remained AIDS-free or the percentage of patients who maintained their CD4 T cell count above entry levels for a long time; the log-rank test (LRt) was used to compare curves. $P$ values $<0.05$ were considered as significant.

\section{Results \\ Two-year clinical events}

The 44 patients entered in the study received $0.5 \mathrm{mg} / \mathrm{kg} /$ day of PDN for six months; PDN was then decreased to $0.3 \mathrm{mg} / \mathrm{kg} /$ day. During the first year, five patients decided to stop taking PDN, two because their CD4 cell count had dropped under 200 cells/ $\mu$ land the other three when their CD4 cells had decreased to less than entry levels; one of them declined further follow-up at our institution at month eight. Of the 11 patients who were taking Zidovudine at the time of starting PDN therapy, five decided to discontinue it at month six. Overall, a total of 39 patients completed the first year of PDN therapy. During the sec- ond year, six patients stopped PDN because their CD4 cells had dropped under 200 cells/ $\mu$ l. Thus, after 24 months, a total of 33 patients were still under PDN and $43 / 44$ were available for evaluation. Of note is the fact that the six patients who were still under Zidovudine when starting their second year of PDN discontinued their antiviral treatment between months 13 and 18 .

Side effects of PDN were mild. Three patients interrupted PDN transiently. Moderate enlargement of the face developed in two patients and a beginning of buffalo neck appeared in one patient during the second year of treatment. Mean weight increased from $66.4 \mathrm{~kg}$ at entry to 67.3 $\mathrm{kg}$ at two years $\left(P_{\mathrm{Wt}}<0.05\right)$. Mean blood pressure slightly increased from $128 / 83 \mathrm{~mm} \mathrm{Hg}$ at entry to $129 / 84 \mathrm{~mm} \mathrm{Hg}$ at two years $\left(P_{\mathrm{Wt}}=\mathrm{NS}\right)$ while glycemia and plasma potassium $\mathrm{K}^{+}$levels remained unchanged.

Lymphadenopathies, which existed in 20 patients at PDN onset disappeared in 16 after one year and in a total of 19 after two years of therapy. Mild oral thrush which existed initially in three patients (all of them with a HVL) developed in 11 others (three with LVL and eight with HVL) who received short courses of antifungal therapy. Clinical AIDS (dementia, cachexia and cerebral toxoplasmosis) developed in three patients 14, 20 and 22 months after PDN onset. At the time of clinical AIDS, they had 101, 24 and $3 \mathrm{CD} 4 \mathrm{~T}$ cells $/ \mu \mathrm{l}$, were off PDN therapy for eight, eight and 16 months respectively and two of them were already receiving RTIs. At PDN onset, these three patients had a HVL and 256, 337 and $361 \mathrm{CD} 4 \mathrm{~T}$ cells/ $\mu$ l respectively.

Among the 74 patients of the control group, mild immunodeficiency symptoms were not recorded but clinical AIDS occurred in 11 patients five to 23 months (median 20) after their entry into the control group. At the time clinical AIDS was diagnosed, all of them had less than 200 $\mathrm{CD} 4 \mathrm{~T}$ cells/ $\mu \mathrm{l}$ and three were already under RTIs. Initially, the mean CD4 T cell count of these 11 patients was 428 cells/ $\mu \mathrm{l}$ (min 246, max 656, median 440). Seven of them had an initial HVL while the remaining four had a LVL.

\section{Two-year serum viral loads evolution}

Viral loads of PDN-treated and control patients were almost similar $\left(P_{\mathrm{MWt}}=\mathrm{NS}\right.$ at each time points $)$ and remarkably stable over time: PDN-treated group: entry, $4.1 \pm 0.1 \log$ copies $/ \mathrm{ml}$; two years, $4.2 \pm 0.1 \log$ copies $/ \mathrm{ml}$ $\left(P_{\mathrm{Wt}}=\mathrm{NS}\right)$; control group: entry $3.8 \pm 0.1 \log$ copies $/ \mathrm{ml}$; two years $3.9 \pm 0.2 \log _{10}$ copies $/ \mathrm{ml}\left(P \mathrm{M}_{\mathrm{Wt}}=\mathrm{NS}\right)$ (Figure 1A). At entry, viral load levels of LVL and HVL subgroups were different $\left(P_{\mathrm{MWt}}<0.01\right)$. However, the evolution of the viral load of PDN-treated and control patients with LVL was almost identical $\left(P_{\mathrm{MWt}}=\mathrm{NS}\right.$ each time point $)$ with a significant increase at two years compared to entry levels $\left(P_{\mathrm{Wt}}<0.01\right.$ in both subgroups) (Figure $\left.1 \mathrm{~B}\right)$, while entry 
A

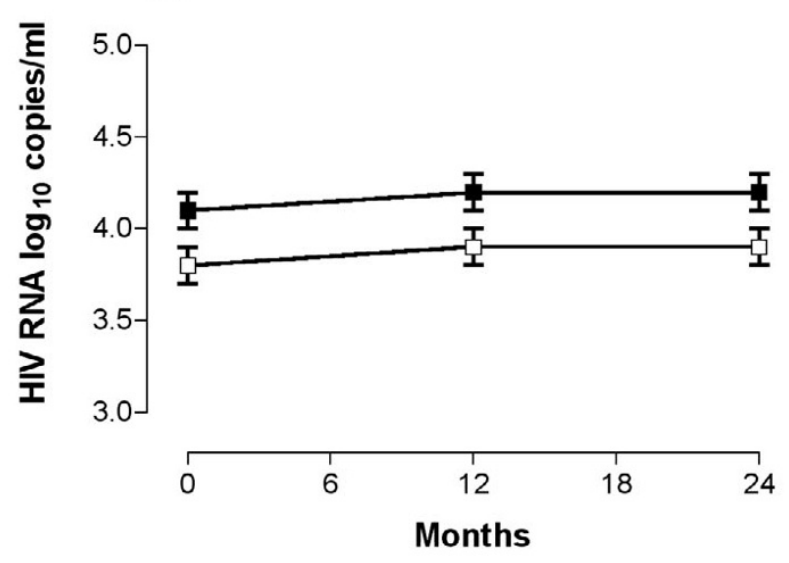

B

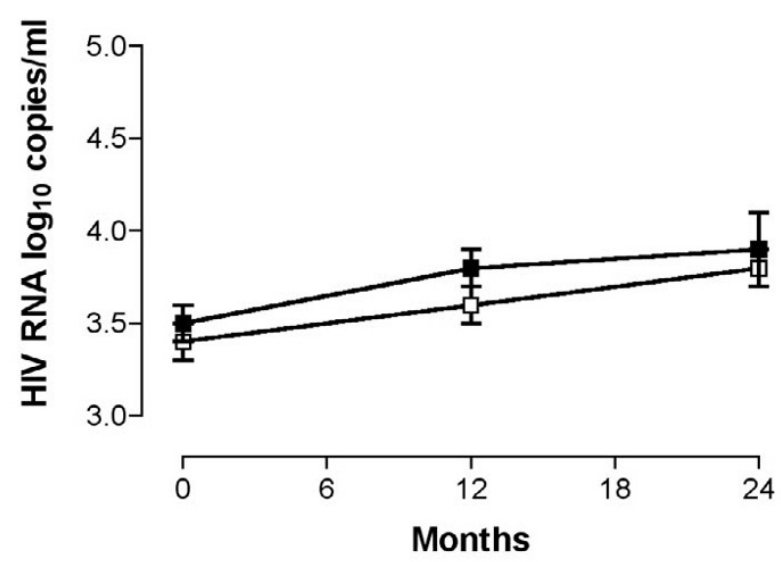

C

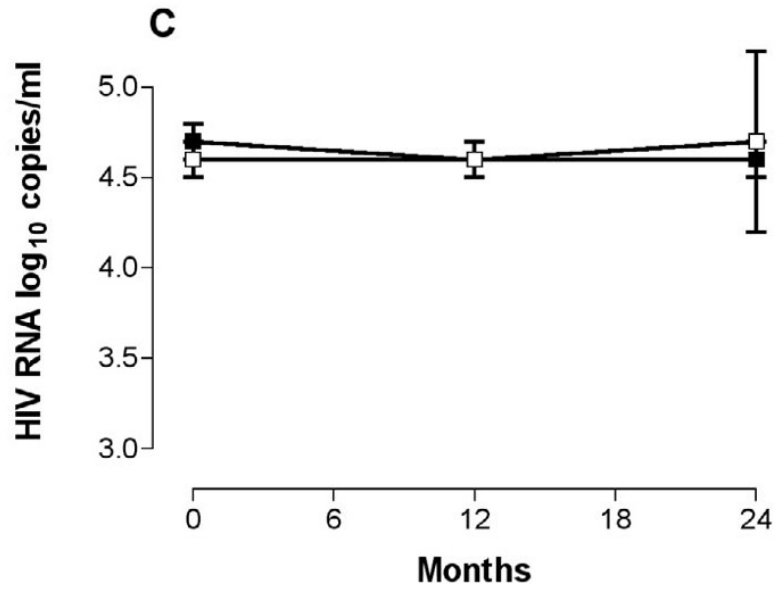

D

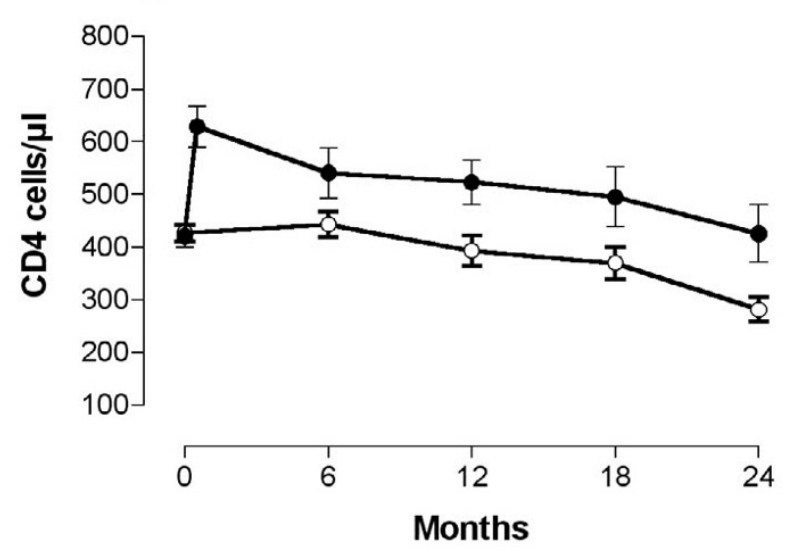

$\mathbf{E}$
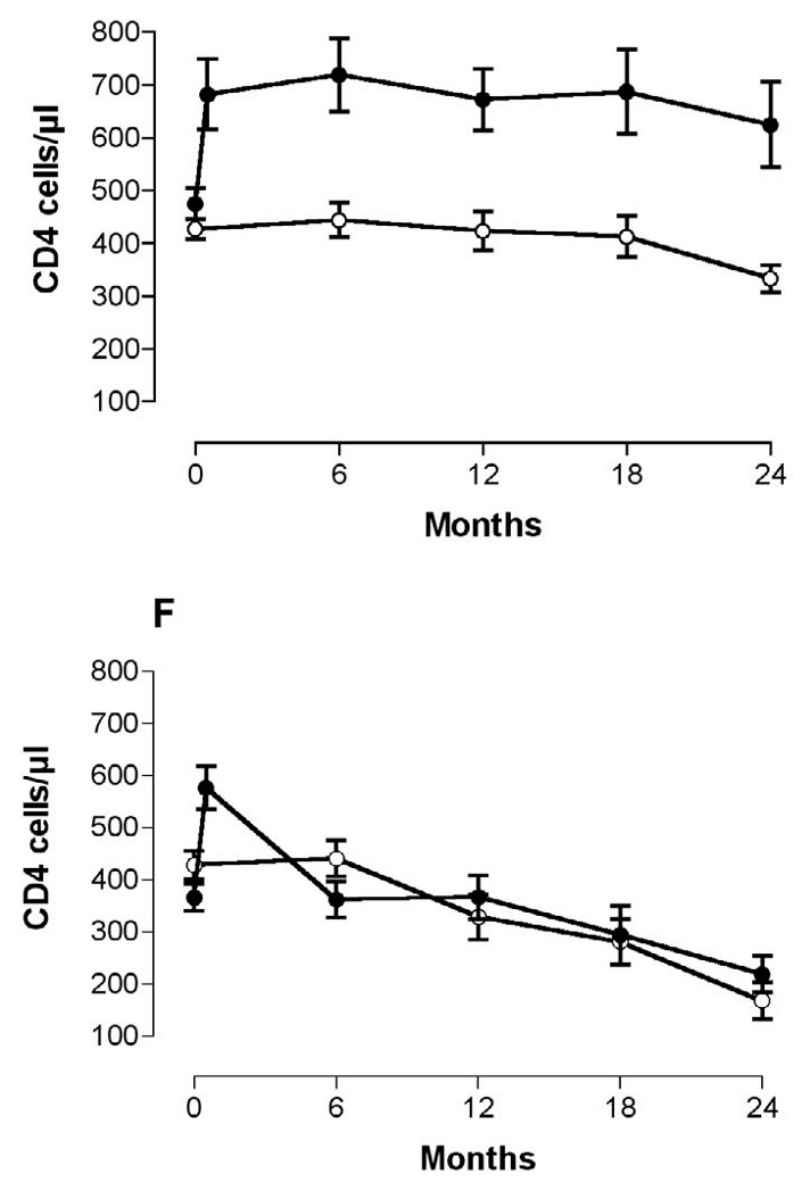

\section{Figure I}

Evolution of serum viral load and CD4 T cell count in 44 PDN-treated patients and 74 control patients. (A-C), Geometric mean \pm SE of serum viral load in PDN-treated patients (filled squares) versus control patients (open squares) of total groups (A) and subgroups with an initial low viral load (LVL) (B) and high viral load (HVL) (C). (D-F), Mean \pm SE of CD4 T cell count in PDN-treated patients (filled circles) versus control patients (open circles) of total groups (D) and subgroups with an initial LVL (E) and HVL (F). 
and two-year viral load levels of PDN-treated and control patients with HVL were similar $\left(P_{\mathrm{MWt}} P=\mathrm{NS}\right.$ at each time points) and remained stable over two years $\left(P_{\mathrm{Wt}}=\mathrm{NS}\right)$ (Figure 1C).

\section{Two-year CD4 T cell count evolution}

In the PDN-treated group, the mean entry level of CD4 T cells was $421 \pm 21$ cells $/ \mu$ l (median 438). At day 15, CD4 T cell count jumped to $629 \pm 39 \mathrm{cell} / \mu \mathrm{l}\left(P_{\mathrm{Wt}}<0.01\right)$; it slowly decreased thereafter to reach $426 \pm 54$ cells/ $\mu$ l after two years $\left(P_{\mathrm{Wt}}\right.$ day 0 - year $\left.2=\mathrm{NS}\right)$ (Figure 1D). The evolution of the CD4 $\mathrm{T}$ cell counts of the 11 patients who were under ziduvidine when starting PDN had the same profile: their CD4 T cells started from lower values $(329 \pm$ 35 cells $/ \mu \mathrm{l})$ than those of the entire PDN-treated group; they also increased at day $15(490 \pm 52$ cells/ $\mu \mathrm{l})$ and then progressively decreased to reach $260 \pm 48$ cells $/ \mu$ lafter two years.

The CD4 T cell count of the control group started at $427 \pm$ 16 cells/ $\mu \mathrm{l}$ at entry (a level almost identical to entry CD4 $\mathrm{T}$ cell count of the PDN-treated group). It then decreased to $282 \pm 23$ cells/ $\mu \mathrm{l}$ after two years of observation (Figure 1D). At each time point (except onset), differences between PDN-treated and control groups were highly significant $\left(P_{\mathrm{MWt}}<0.01\right)$.

\section{Two-year impact of initial viral load on CD4 T cell evolution}

In the PDN-treated group, entry CD4 T cells were $475 \pm 30$ cells/ $\mu \mathrm{l}$ in the 22 patients with a LVL and $366 \pm 26$ cells/ $\mu \mathrm{l}$ in the 22 patients with a HVL. At day 15, patients of both subgroups had increased their CD4 T cells (up to 682 $\pm 67 / \mu \mathrm{l}$ in LVL patients, $P_{\mathrm{Wt}}<0.01$, and to $577 \pm 41$ cells/ $\mu \mathrm{l}$ in HVL patients $\left(P_{\mathrm{Wt}}<0.05\right)$. At month 24 , the mean CD4 T cell count of LVL patients was still $625 \pm 81$ cells/ $\mu \mathrm{l}\left(P_{\mathrm{Wt}}\right.$ day 0 to two years $<0.01, P_{\mathrm{Wt}}$ day 15 to two years $=\mathrm{NS}$, Figure 1E, filled circles). In contrast, the mean CD4 T cell count of HVL patients had dropped to $219 \pm 34$ cells/ $\mu \mathrm{l}$, a value significantly lower than those of day 0 and day 15 ( $P_{\mathrm{Wt}}<0.05$ Figure $1 \mathrm{~F}$, filled circles). Comparison of HVL and LVL subgroups treated by PDN demonstrate no significant difference at day $0\left(P_{\mathrm{MWt}}=\mathrm{NS}\right)$ or day $15\left(P_{\mathrm{MWt}}\right.$ $=$ NS) but a highly significant difference at each time points thereafter $\left(P_{\mathrm{MWt}}<0.01\right)$.

In control patients, mean CD4 count at entry was $427 \pm$ 19 cells/ $\mu$ l in the 51 patients with a LVL and $428 \pm 27$ cells/ $\mu \mathrm{l}$ in the 23 patients with a HVL. In each subgroup, CD4 T cells decreased progressively thereafter to reach, after two years, $333 \pm 26$ cells $/ \mu l$ in LVL patients $\left(P_{\mathrm{Wt}}\right.$ entry to two years $<0.01$ ) and $168 \pm 36$ cells/ $\mu$ l in HVL patients ( $P_{\mathrm{Wt}}$ entry to two years $<0.01$ Figure $1 \mathrm{E}, 1 \mathrm{~F}$, open circles). Comparison of HVL and LVL control subgroups demonstrated no difference at day 0 but a highly significant dif- ference at each time point $(6,12,18$ and 24 months) thereafter $\left(P_{\mathrm{MWt}}<0.01\right)$.

The comparative evaluation of PDN-treated and control patients with LVL showed that entry CD4 T cells of the 22 PDN-treated and the 51 control patients were not significantly different $\left(P_{\mathrm{MWt}}=\mathrm{NS}\right)$. However, because of the large increase observed from day 15 in PDN-treated patients, the difference between the two LVL subgroups was significantly different at each time point $(6,12,18$ and 24 months $)$ thereafter $\left(P_{\mathrm{MWt}}<0.05\right)$ while the slopes of both curves were almost parallel (from day 15) (Figure $1 \mathrm{E})$.

In HVL subgroups (22 PDN-treated and 23 control patients), entry CD4 T cells were similar $\left(P_{\mathrm{MWt}}=\mathrm{NS}\right)$. However the CD4 T cell increase observed at day 15 in PDN-treated patients was only transient and there was no difference between the two curves at each time point $(6$, $12,18,24$ months $)$ thereafter $\left(P_{\mathrm{MWt}}=\mathrm{NS}\right.$, Figure $\left.1 \mathrm{~F}\right)$.

\section{Two-year evolution of total lymphocytes of the PDN- treated group}

The total lymphocytes count followed the same profile as that of the CD4 T cells count (Figure 2) while CD8 T cells remained almost stable $\left(P_{\mathrm{MWt}}\right.$ day 0 to two years $=\mathrm{NS}$ ) and not significantly different $\left(P_{\mathrm{Wt}}=\mathrm{NS}\right.$ at each time point) in the LVL and HVL PDN-treated subgroups (data not shown).

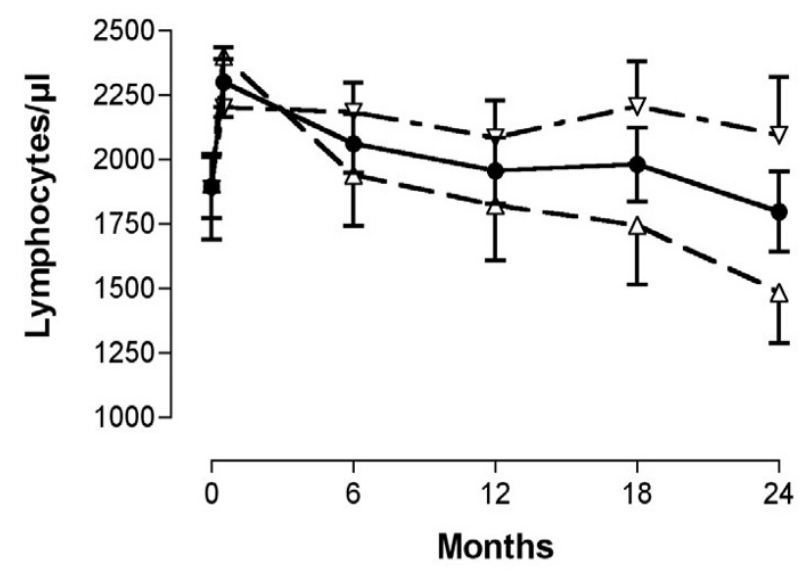

\section{Figure 2}

Evolution of total lymphocyte count in PDN-treated patients. Mean \pm SE of lymphocyte count in total group (filled circles) and subgroups with an initial LVL (down-pointing triangles) and HVL (up-pointing triangles). 


\section{A}

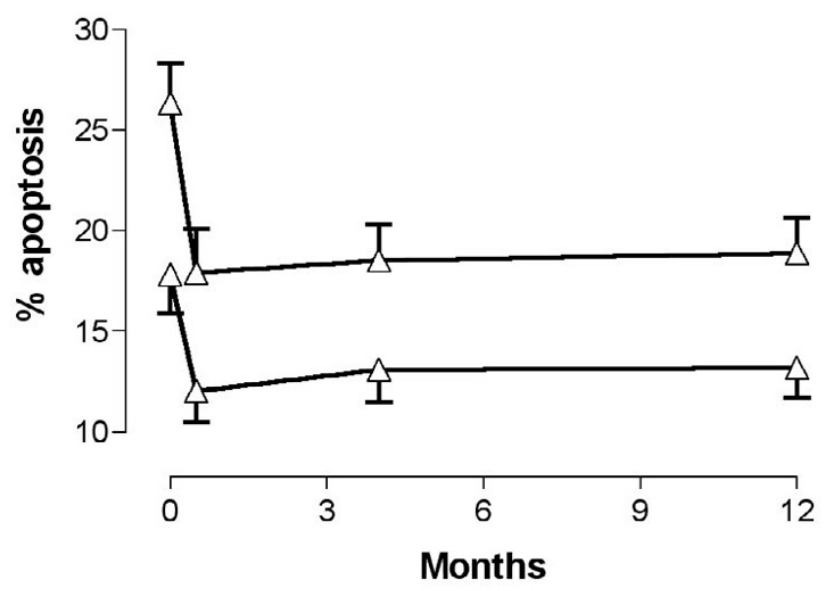

C

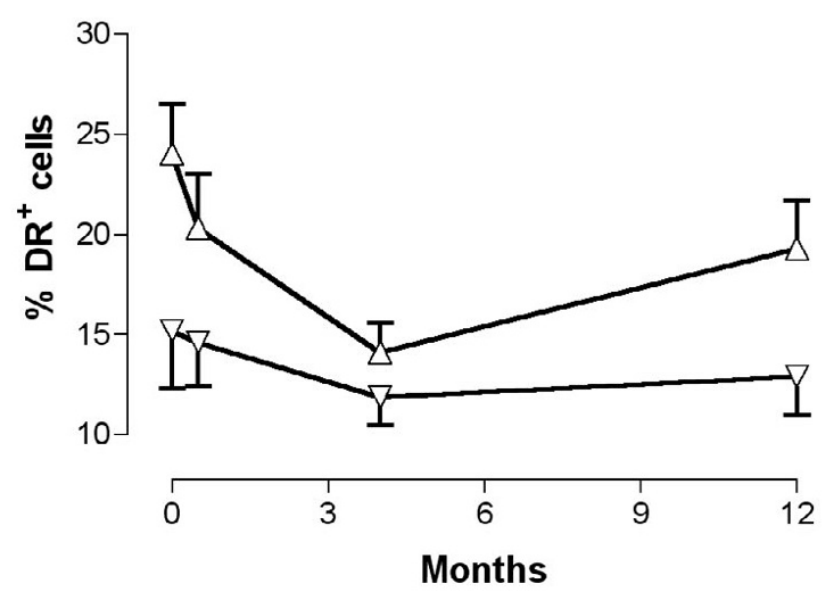

B

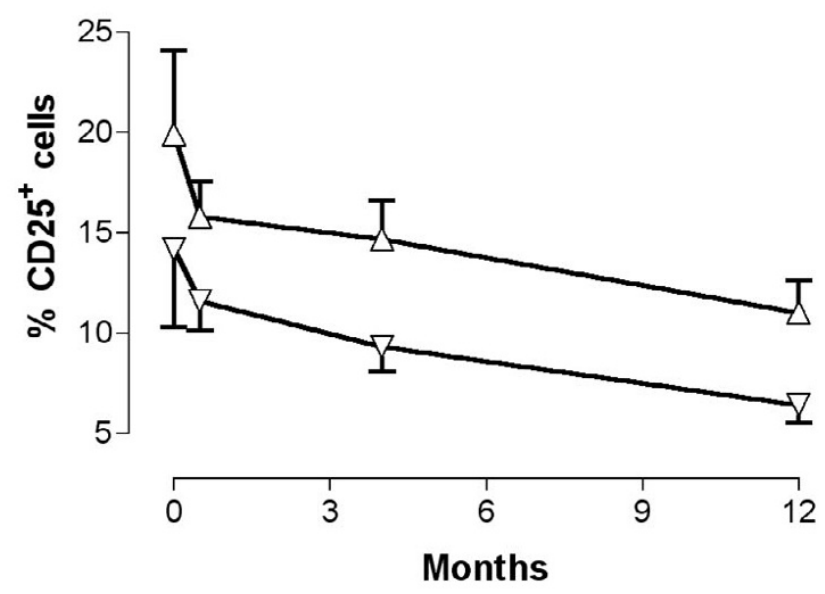

D

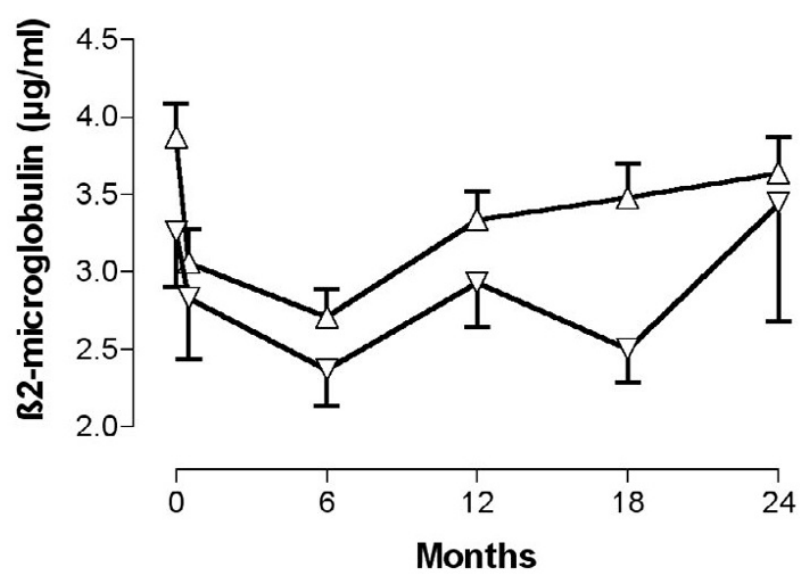

\section{Figure 3}

Evolution of the percentage of apoptotic cells in PBMC, CD25+ and DR+ cells in CD4 T cells, and serum $\beta 2$-microglobulin in PDN-treated patients. Mean \pm SD of the percentage of apoptotic cells in PBMC (A), CD25+ cells in CD4 T cells (B), DR ${ }^{+}$cells in CD4 T cells (C) and $\beta 2$-microglobulin (D) in subgroups with an initial LVL (down-pointing triangles) and HVL (up-pointing triangles).

Two-year evolution of activation and apoptosis markers in PDN-treated patients

The percentage of apoptotic cells in PBMC started from 21 $\pm 10 \%$; it substantially decreased to $15 \pm 9 \%$ at day $15\left(P_{\mathrm{Wt}}\right.$ $<0.01)$ and remained decreased at one year $(14 \pm 5 \%$, $\left(P_{\mathrm{Wt}}\right.$ day 0 to one year) (Figure $\left.3 \mathrm{~A}\right)$. The percentage of CD25+ and DR ${ }^{+}$phenotypes in CD4 cells followed almost the same profile; it started from $17 \pm 3 \%$ at day 0 , and then decreased to $14 \pm 1 \%$ at day $15\left(P_{\mathrm{Wt}}=\mathrm{NS}\right), 12 \pm 1 \%$ at month $4\left(P_{\mathrm{Wt}}<0.03\right)$ and $9 \pm 1 \%$ at one year $\left(P_{\mathrm{Wt}}<0.01\right)$ (Figure $3 \mathrm{~B})$. Finally, the percentage of $\mathrm{DR}^{+}$cells started from $20 \pm 2 \%$ at day 0 , decreased to $17 \pm 2 \%$ at day 15 $\left(P_{\mathrm{Wt}}=\mathrm{NS}\right), 13 \pm 1 \%$ at month $4\left(P_{\mathrm{Wt}}<0.01\right)$ and remained significantly decreased at one year $\left(18 \pm 3, P_{\mathrm{Wt}}<0.05\right)$ (Figure 3C).

$\beta 2$ microglobulin levels also decreased in PDN-treated patients from $3.6 \pm 0.2 \mathrm{mg} / \mathrm{l}$ at day 0 , to $3 \pm 0.2 \mathrm{mg} / \mathrm{l}$ at day $15\left(P_{\mathrm{Wt}}<0.01\right)$ and $2.5 \pm 0.2 \mathrm{mg} / \mathrm{l}$ at month $6\left(P_{\mathrm{Wt}}<\right.$ $0.01) ; \beta 2$ microglobulin concentration then slowly reincreased thereafter but remained significantly lower than that of entry: $3.1 \pm 0.3 \mathrm{mg} / \mathrm{l}$ at month $12,\left(P_{\mathrm{Wt}}<\right.$ 


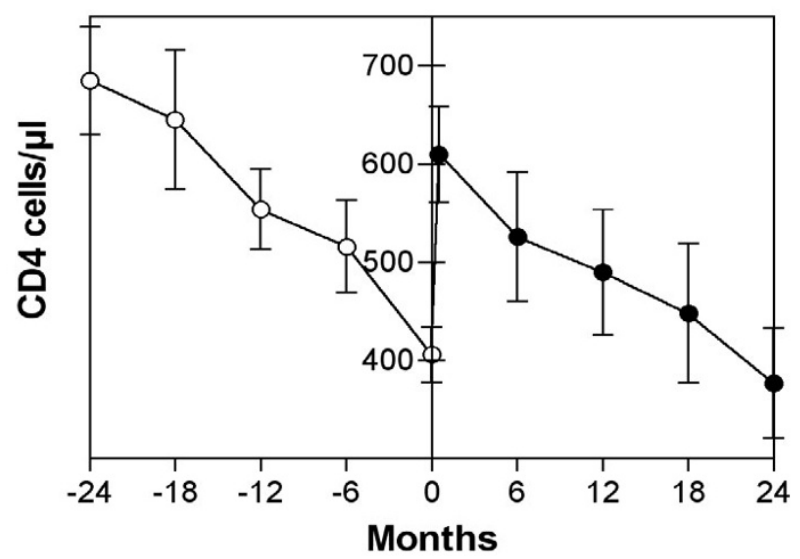

\section{Figure 4}

Evolution of CD4 T cell counts in 24 patients before and under prednisolone. Mean \pm SE of CD4 T cell counts before (open circles) and under prednisolone (filled circles).

$0.01), 3.1 \pm 0.2 \mathrm{mg} / \mathrm{l}$ at month $18\left(P_{\mathrm{Wt}}<0.01\right)$ and $3.4 \pm$ $0.4 \mathrm{mg} / \mathrm{l}$ at year $2\left(P_{\mathrm{Wt}}<0.05\right)$ (Figure $\left.3 \mathrm{D}\right)$.

At entry, the above-mentioned markers were significantly different in LVL and HVL subgroups (percentage of apoptotic cells in PBMC, $P_{\mathrm{MWt}}<0.01$; percentages of CD25+ and $\mathrm{DR}^{+}$cells in CD4 T cells, $P_{\mathrm{MWt}}<0.01$; serum $\beta 2$ microglobulin, $\left.P_{\mathrm{MWt}}=0.03\right)$ and these values remained significantly different $\left(P_{\mathrm{Wt}}<0.05\right.$ until month 12 for all cellular markers and until month 18 for $\beta_{2}$ microglobulin (Figures 3A,3B,3C,3D).

\section{Two-year probabilities of AIDS}

Among the 44 patients of the PDN-treated group, CD4 T cell counts decreased to less than 200 cells/ $\mu$ l (a level which defines AIDS) in nine patients including the three patients who developed clinical AIDS. These nine patients belonged to the subgroup of 22 patients with HVL. Twoyear AIDS free rates were thus very different in the LVL subgroup (100\%) and the HVL subgroup (59.1 $\pm 10 \%$, $\left.P_{\text {LRt }}<0.01\right)$.

Among the 74 patients of the control group, CD4 T cells of 31 patients decreased to less than 200 cells/ $\mu$ l, of whom 11 patients developed clinical AIDS. Among these 31 patients, 16 belonged to the subgroup of 23 patients with HVL while the remaining 15 belonged to the subgroup of 51 patients with LVL. Two-year AIDS free rates were thus $70.1 \pm 6 \%$ for the LVL subgroup versus $30.4 \pm .9 \%$ for the HVL subgroup $\left(P_{\text {LRt }}<0.01\right)$.
Comparison of PDN-treated and control patients showed that by two years, $79.5 \pm 6 \%$ of the PDN-treated patients remained AIDS-free versus $57.6 \pm 6 \%$ of the control group $\left(P_{\mathrm{LRt}}=0.02\right)$. All patients $(100 \%)$ of the PDN-treated subgroup with LVL remained AIDS-free versus $70 \pm 6 \%$ of the LVL control subgroup $\left(P_{\text {LRt }}<0.01\right)$; in contrast, AIDS-free rates were only $59.1 \pm 10 \%$ for the HVL PDN-treated patients and $30.4 \pm 9 \%$ for the HVL control patients $\left(P_{\mathrm{LRt}}\right.$ $=$ NS).

\section{CD4 $T$ cell counts and viral load levels before and under prednisolone}

Among the 44 patients who started PDN, 25 were already followed in our institution during the two years preceding PDN onset (as already mentioned in Methods). During this two-year period, the mean CD4 T cell count of these 25 patients decreased from $688 \pm 57$ cells/ $\mu$ l (month -24 ) to $409 \pm 28$ cells $/ \mu$ l (PDN onset). Once under PDN the mean CD4 T cell count of these 25 patients followed the same profile $(603 \pm 53 \mathrm{cell} / \mu \mathrm{l}$ at day 15 and $387 \pm 57$ cells/ $\mu$ l at month 24 , Figure 4 ) as that of the entire PDNtreated group. Mean viral load of these 25 patients remained stable whether they were off PDN or on PDN (24 months: $4.13 \pm 0.14 \log$ copies/ml, PDN onset: $4.11 \pm$ $0.12 \log$ copies $/ \mathrm{ml},+24$ months $4.17 \pm 0.13$ log copies/ $\mathrm{ml}), P_{\mathrm{Wt}}=\mathrm{NS}$ at each time point).

\section{Ten-year results of prednisolone treatment}

From the third year, PDN was maintained only in the patients whose CD4 T cells remained over entry levels and no patient, whether belonging to the PDN-treated or to the control group, developed clinical AIDS or started any antiretroviral therapy while having CD4 T cells over entry levels. The long-term impact of PDN on the evolution of HIV-infection was therefore evaluated by measuring the Kaplan-Meier percentage of patients maintaining their CD4 $\mathrm{T}$ cell count above entry for a long time (since all patients were receiving PDN at least until such CD4 T cell levels). The percentage of patients of the control group maintaining their CD $4 \mathrm{~T}$ cell count over baseline was also calculated. By two years, $43.2 \pm 7.5 \%$ of the PDN group maintained their CD4 T cell count over entry; by five years, $11.4 \pm 4.8 \%$ had still increased CD4 T cell counts (Figure 4). Finally, by ten years (30 March 2003), two patients $(4.6 \pm 2 \%)$ were still under PDN with CD4 cell counts over entry. In contrast, in the control group, percentages of patients with CD4 T cells remaining over entry were $12.2 \pm 3.1 \%, 1.3 \pm 1.3 \%$ and $0 \%$ at two, five and ten years respectively $\left(P_{\text {LRt }}<0.01\right)$ (Figure $\left.5 \mathrm{~A}\right)$.

The impact of initial viral load on the percentage of patients maintaining their CD4 T cells over baseline was strong. By two, five and ten years, $72.7 \pm 9.5 \%, 22.7 \pm$ $8.9 \%$ and $9.1 \pm 4 \%$ of the PDN-treated patients with LVL 

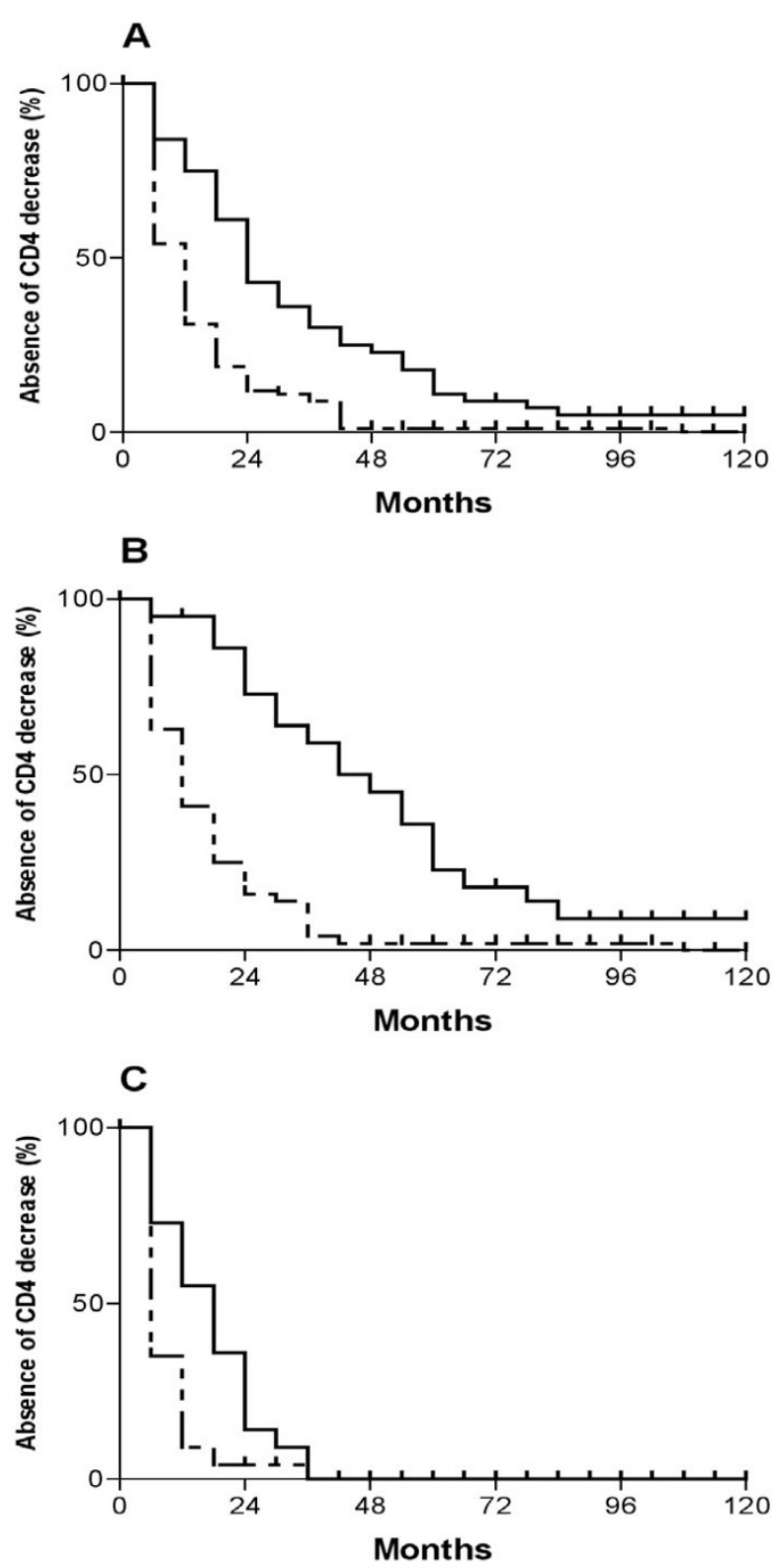

\section{Figure 5}

Absence of CD4 T cell decrease in PDN-treated and control patients over 10 years. Percentage of patients maintaining their CD4 T cells over entry level in PDN-treated patients (solid lines) versus control patients (dashed lines) of total groups (A) and subgroups with an initial LVL (B) and HVL (C).

maintained their CD4 cells over baseline versus $13.6 \pm$ $7.3 \% 0 \%$ and $0 \%$ of those with HVL $\left(P_{\mathrm{LRt}}<0.01\right)$.
In control patients, by two, five and ten years, $15.7 \pm$ $5.1 \%, 2 \pm 2 \%$ and $0 \%$ of the LVL subgroup maintained their CD4 T cells versus $4.3 \pm 4.2 \%, 0 \%$ and $0 \%$ in the HVL subgroup $\left(P_{\mathrm{LRt}}=0.01\right)$. In patients with LVL the ten-year percentage of patients with no CD4 cell decrease was higher in PDN-treated patients $(9.1 \%)$ than in control patients $\left(0 \%, P_{\mathrm{LRt}}<0.01\right.$, Figure $\left.5 \mathrm{~B}\right)$.

In contrast, in patients with HVL the percentage of patients maintaining their CD4 T cells over entry was only significantly increased for up to two years in PDN-treated patients $(13.6 \%)$ compared to control patients $(0 \%)(P<$ $0.05)$ (Figure 5C).

\section{Discussion}

Prednisolone, an immunosuppressive drug belonging to the GC family was given at moderate doses to $44 \mathrm{HIV}$ infected patients with CD4 T cells ranging from 207 to 775 cells/ $\mu$ l. Side effects were mild; no patient on PDN or after PDN withdrawal developed symptoms of hip necrosis, the fear of which was the cause of the premature arrest at eight weeks of a double-blind trial testing prednisone versus a placebo [8].

The marked increase in the CD4 cell count observed in PDN-treated patients at day 15 was in striking contrast with the well-known GC-induced CD4 T lymphopenia observed in normal subjects [9]. Importantly, this CD4 T cell increase occurred without any modification of the viral load. Moreover, it was associated with a symmetric decrease in the serum $\beta 2$-microglobulin concentration, the percentage of apoptotic peripheral blood lymphocytes and the percentage of CD4 T cells bearing $\mathrm{DR}^{+}$or CD25+ markers. It is reasonable to suspect that these modifications are representative of the inhibition of the abnormal activation-induced $\mathrm{T}$ cell apoptosis in lymphoid tissues proper to the chronic phase of HIV infection. Moreover it is also conceivable that GCs could delay or even stop CD4 T cell homing and apoptosis in lymph nodes by down-regulating L-selectin on peripheral lymphocytes [10]. The absence of modification of serum viral load in spite of the strong CD4 cell increase suggests that the CD4 T cells, which were prevented from dying by PDN, were not productively infected. This is in keeping with our in vitro observations showing that PDN did not modify HIV replication but antagonized activationinduced apoptosis of non-infected T cells [4]. Altogether, these results argue against the paradigm assuming that the CD4 T cell depletion from lymphoid tissues was mainly due to the cytopathic effect of the virus on CD4 T cells and to the incapacity of the immune system to replace these cells in time [11-13]. On the contrary, our results bring experimental arguments in favor of the concept that HIVinduced immune activation is at least in part the cause of the depletion of (non-infected) CD4 T cells $[14,15]$. 
Although the peripheral CD4 cell count has been shown to be a good surrogate marker of the immunologic evolution of patients without treatment as well as of those under highly active anti-retroviral therapy (HAART), it remains that, in PDN-treated patients, we have no information on what happens in the lymphoid tissues which are the site of both HIV replication, T cell proliferation, differentiation and apoptosis.

After the initial increase of the CD4 cell count, although the viral load remained remarkably stable, PDN (at the dose at which it was given) was probably no longer able to fight both $\mathrm{T}$ cell-activation and apoptosis processes in the subgroup of patients with a HVL. In contrast, in patients with a LVL, abnormal HIV-induced T cell activation and apoptosis were controlled by PDN for up to 10 years in a fraction $(9.1 \%)$ of the patients (Figure $5 \mathrm{~B}$ ).

The absence of viral load increase under PDN questions the role of cytotoxic CD8 T lymphocytes in the chronic phase of HIV infection. Since it has recently been demonstrated that GCs are capable of inhibiting the differentiation of dendritic cells (the most potent antigenpresenting and T-cell stimulating cells) in vitro [16], it is conceivable that the number of HIV-specific CD8 T cells of PDN-treatment patients could be somehow reduced. If HIV-specific CD8 T cells play a significant role in controlling viral replication (via their cytolytic activity toward productively infected CD4 T cells), an increase in plasma HIV RNA levels should be expected in patients under PDN (at least within the first months of PDN-treatment during which in vivo T-cell reactivity was significantly down-regulated). The present study showed that it was not the case. It is established that HIV-specific memory CD8 T cells do exist along the chronic phase of the infection as shown by HIV peptides HLA tetramers [17] and that they can differentiate in vitro in functional effector cells (that is, capable of suppressing viral replication in infected CD4 T cells) following adequate stimulation [18-20]. However in vivo functional (terminally differentiated) effector CD8 T cells are lacking in patients with chronic HIV infection [21-23].

This retrospective study obviously does not have the demonstrative strength of a prospective randomized trial. However, the 25 patients who were followed in our institution during the two years preceding PDN onset (internal control) and the 74 individuals of the control group (external control) allowed us to draw some firm conclusions at least on $\mathrm{CD} 4 \mathrm{~T}$ cells count, the main surrogate marker of the immune system's progressive destruction along the course of HIV infection [24], and viral load evolution under PDN. Overall, the progressive CD4 T cell count decrease proper to the chronic phase of HIV infection was postponed for two years (Figures 1D and 4). Initial viral loads were highly predictive of the CD4 T cell evolution both in the PDN-treated group and the control group (Figure 1E,1F) and, after two years, AIDS occurred significantly less frequently in the PDN-treated group than in the control group $\left(P_{\mathrm{LR}}=0.02\right)$. This is particularly true when comparing PDN-treated and control patients with LVL $\left(P_{\text {LRt }}<0.01\right)$.

Results of this long-term study suggest several types of randomized trials. In developed countries (where HAART treatments and frequent immuno-virologic measurements are available), GCs should be tried in association with HAART versus HAART alone in primary infection. CSA, a more immunosuppressive and more toxic drug than PDN has recently been given in this setting with success [25]. In the chronic phase of the infection, several doses of PDN or other compounds of the GC family should be tested versus a placebo in patients without AIDS and with $<30,000$ HIV RNA copies/ml in order to define the best type and the lowest dose of GCs capable of maintaining CD4 T cell counts over entry (or a predefined level) without excessive toxicity and without developing AIDS. The objective of such trials should be to delay the moment where HAART (with its well-known long-term side effects) should be started.

In developing countries (where access to antiretroviral treatments is limited), PDN should be tried versus a placebo or no treatment in patients without opportunistic infections. Such studies should only be started after having carefully checked the absence of evolutive infections (such as tuberculosis) susceptible to be worsened by the long-term use of GCs. In the context of developing countries, the main entry and endpoint criteria could be the peripheral blood total lymphocytes count, which was shown (Figure 3) to be a good surrogate marker of CD4 cell evolution under PDN. A randomized trial measuring the time during which total lymphocytes remain over entry (or a pre-defined) level and the percentage of clinical AIDS episodes within this duration would be of use in evaluating the duration of time during which GCs could delay the moment where AIDS develops, and/or anti-viral therapies (if available) should be given.

\section{Conclusions}

Prednisolone postponed CD4 cell decrease in a viral load dependent manner for a median of two years and for up to 10 years in a fraction of patients with a low viral load. These findings might stimulate clinical trials as well as biological research on the role of antiapoptotic drugs in HIV infection.

\section{Competing interests}

None declared. 


\section{List of abbreviations}

GCs, glucocorticoids; PDN, prednisolone; CSA, cyclosporine A; HVL, high viral load; LVL, low viral load; Wt, Wilcoxon matched paired single rank test; Mwt, Mann-Whitney test; Lrt, log-rank test; HAART, highly active anti-retroviral therapy.

\section{Authors' contributions}

JMA carried out the clinical study and drafted the manuscript. WL performed immunologic and virologic analysis. Both authors contributed to the study design, the data analysis, and approved the final manuscript.

\section{Acknowledgements}

We are grateful to all our patients for their confidence. We thank Drs W Lowenstein, M Stern and JM Tourani who carefully followed some of the patients; J Yuan and R Salerno Goncalvez for excellent technical assistance.

\section{References}

1. Andrieu JM, Even P, Venet A: AIDS and related syndromes as a viral-induced autoimmune disease of the immune system: an anti-MHC II disorder. Therapeutic implications. AIDS Res 1986, 2:163-174.

2. Andrieu JM, Even P, Venet A, Tourani JM, Stern M, Lowenstein W Audroin C, Eme D, Masson D, Sors H: Effects of cyclosporin on T-cell subsets in human immunodeficiency virus disease. Clin Immunol Immunopathol 1988, 47:181-198.

3. Levy R, Jais JP, Tourani JM, Even P, Andrieu JM: Long-term followup of HIV positive asymptomatic patients having received cyclosporin A. Adv Exp Med Biol 1995, 374:229-234.

4. Lu W, Salerno-Goncalves R, Yuan J, Sylvie D, Han DS, Andrieu JM: Glucocorticoids rescue CD4+ $T$ lymphocytes from activation-induced apoptosis triggered by HIV-I: implications for pathogenesis and therapy. AIDS 1995, 9:35-42.

5. Andrieu JM, Lu W, Levy R: Sustained increases in CD4 cell counts in asymptomatic human immunodeficiency virus type I-seropositive patients treated with prednisolone for I year. J Infect Dis 1995, I 7 I:523-530.

6. Nicoletti I, Migliorati G, Pagliaci MC, Grignani F, Riccardi C): A rapid simple method for measuring thymocyte apoptosis by propidium iodide staining and flow cytometry. J Immunol Methods |99|, |39:27|-279.

7. Lu W, Cao L, Ty L, Arlie M, Andrieu JM: Equivalent amplification of intrinsically variable nucleic acid sequences by multipleprimer-induced overlapping amplification assay: applications for universal detection and quantitation. Nat Med 1999, 5:1081-1085.

8. Wallis RS, Kalayjian R, Jacobson JM, Fox L, Purdue L, Shikuma CM Arakaki R, Snyder S, Coombs RW, Bosh RJ, Spritzler J, Chemoff M, Aga $E$, Myers L, Schock B, Lederman MM: A study of the immunology, virology and safety of Prednisone in HIV-I infected subjects with CD4 cell counts of 200 to $700 \mathbf{~ m m}^{-3}$. J Acquir Immune Defic Syndr 2003, 32:281-286.

9. Fauci AS, Dale DC, Balow JE: Glucocorticosteroid therapy: mechanisms of action and clinical considerations. Ann Intern Med 1976, 84:304-3।5.

10. Cloyd MW, Chen J], Adeqboyega P, Wang L: How does HIV cause depletion of CD4 lymphocytes? A mechanism involving virus signaling through its cellular receptors. Curr Mol Med 2001 , I:545-550

II. Ho DD, Neumann AU, Perelson AS, Chen W, Leonard JM, Markowitz $M$ : Rapid turnover of plasma virions and CD4 lymphocytes in HIV-I infection. Nature 1995, 373:123-126.

12. Wei X, Ghosh SK, Taylor ME, Johnson VA, Emini EA, Deutsch P, Lifson JD, Bonhoeffer S, Nowak MA, Hahn BH: Viral dynamics in human immunodeficiency virus type I infection. Nature 1995 373: $117-122$.

13. Perelson AS, Neumann AU, Markowitz M, Leonard JM, Ho DD: HIVI dynamics in vivo: virion clearance rate, infected cell lifespan, and viral generation time. Science 1996, 27 I: I582-I586.
14. Andrieu JM, Lu W: Viro-immunopathogenesis of HIV disease: implications for therapy. Immunol Today 1995, 16:5-7.

15. Grossman Z, Meier-Schellersheim M, Sousa AE, Victorino RM, Paul WE: CD4+ T-cell depletion in HIV infection: are we closer to understanding the cause? Nat Med 2002, 8:319-323.

16. Relloso M, Puig-Kroger A, Pello OM, Rodriguez-Fernandez JL, de la Rosa G, Longo N, Navarro J, Munoz-Fernandez MA, Sanchez-Mateos $P$, Corbi AL: DC-SIGN (CD 209) expression is IL-4 dependant and is negatively regulated by IFN, TGF-beta, and antiinflammatory agents. I Immunol 2002, 168:2634-2643.

17. Altman JD, Moss PA, Goulder PJ, Barouch DH, McHeyzer-Williams MG, Bell JI, McMichael AJ, Davis MM: Phenotypic analysis of antigen-specific T lymphocytes. Science 1996, 274:94-96.

18. Salerno-Goncalves R, Lu W, Achour A, Andrieu JM: Lysis of CD4+ $T$ cells expressing HIV-I gag peptides by gag-specific CD8+ cytotoxic T cells. Immunol Lett 1998, 64:71-77.

19. Lu W, Achour A, Arlie M, Cao L, Andrieu JM: Enhanced dendriticcells-driven proliferation and anti-HIV activity of CD8+ T cells by a new phenothiazine derivative aminoperazine. J Immunol 2001, 167:2929-2935.

20. Lu W, Andrieu JM: In vitro HIV eradication by autologous CD8+ $T$ cells expanded with inactivated-virus-pulsed dendritic cells. I Virol 200I, 75:8949-8956.

21. Appay V, Nixon DF, Donahoe SM, Gillespie GM, Dong T, King A, Ogg GS, Spiegel HM, Conlon C, Spina CA, Havlir DV, Richman DD, Waters A, Easterbrook P, McMichael AJ, Rowland-Jones SL: HIVspecific CD8(+) $T$ cells produce antiviral cytokines but are impaired in cytolytic function. J Exp Med 2000, 192:63-75.

22. Champagne P, Ogg GS, King AS, Knabenhans C, Ellefsen K, Nobile M, Appay V, Rizzardi GP, Fleury S, Lipp M, Forster R, Rowland-Jones S, Sekaly RP, McMichael AJ, Pantaleo G: Skewed maturation of memory HIV-specific CD8 T lymphocytes. Nature 200I, 410:106-III.

23. Kostense S, Vandenberghe K, Joling J, Van Baarle D, Nanlohy N, Manting E, Miedema F: Persistent numbers of tetramer(+) CD8(+) T cells, but loss of interferon-gamma(+) HIV-specific $T$ cells during progression to AIDS. Blood 2002, 99:2505-25I I.

24. Fahey JL, Taylor JM, Detels R, Hofmann B, Melmed R, Nishanian P, Giorgi JV: The prognostic value of cellular and serologic markers in infection with human immunodeficiency virus type $I$. N Engl J Med 1990, 322:166-172.

25. Rizzardi GP, Harari A, Capiluppi B, Tambussi G, Ellefsen K, Ciuffreda D, Champagne P, Bart PA, Chave JP, Lazzarin A, Pantaleo G: Treatment of primary HIV-I infection with Cyclosporin A coupled with highly active antiretroviral therapy. J Clin Invest 2002, 109:68|-688.

\section{Pre-publication history}

The pre-publication history for this paper can be accessed here:

http://www.biomedcentral.com/1741-7015/2/17/prepub

Publish with Biomed Central and every scientist can read your work free of charge

"BioMed Central will be the most significant development for disseminating the results of biomedical research in our lifetime. "

Sir Paul Nurse, Cancer Research UK

Your research papers will be:

- available free of charge to the entire biomedical community

- peer reviewed and published immediately upon acceptance

- cited in PubMed and archived on PubMed Central

- yours - you keep the copyright
BioMedcentral 